\title{
COMPARATIVE STUDY OF LEARNING RESULTS TO DRAW PERSPECTIVE USING CULTURAL AND CONVENTIONAL PEER TEACHERS LEARNING METHODS
}

\author{
Indra Mawan Sitepu', Sugito² \\ 1, 2 Fakultas Bahasa Dan Seni \\ Universitas Negeri Medan, Indonesia. \\ Jl. Willem Iskandar / Pasar V , Medan-Sumatera Utara \\ E-mail: indramawansitepu@gmail.com, sugitoas@gmail.com
}

\begin{abstract}
Abstrak
Penelitian ini bertujuan untuk membuktikan perbandingan hasil belajar peserta didik dalam menggambar perspektif menggunakan metode pembelajaran tutor sebaya dan konvensional. Populasi dalam penelitian ini adalah seluruh karya peserta didik kelas X IPA (3 kelas) dan peserta didik kelas X IPS (3 kelas) dan diperoleh sampel penelitian yaitu sebanyak 36 peserta didik atau 72 karya. Pada sampel ini diberi dua tahap tindakan yaitu pengambilan sampel awal dengan proses belajar-mengajar menggunakan metode pembelajaran konvensional. Berdasarkan hasil penelitian diperoleh rata-rata nilai tes pertama sebesar 71,43 dan nilai tes kedua 82,74. Hasil uji perbedaan rata-rata menunjukkan bahwa rata-rata nilai kedua lebih baik dari pada nilai pertama. Berdasarkan hasil uji hipotesis dengan signifikansi $\alpha=0,5$ dengan dk 70 didapat $t_{\text {tabel }}=1,6669$. Jadi hasil uji hipotesis diperoleh $t_{\text {hitung }} 5,52>t_{\text {tabel }} 1,6669$. Jadi $\mathrm{H}_{\mathrm{a}}$ diterima sekaligus ditolak $\mathrm{H}_{\mathrm{o}}$ kemudian kesimpulannya adalah terdapat perbedaan yang signifikan pada hasil karya menggambar perspektif dengan metode pembelajaran tutor sebaya.

Kata Kunci: Metode Pembelajaran, Hasil Belajar.
\end{abstract}

\begin{abstract}
This study aims to prove the comparison of student learning outcomes in perspective drawing using peer tutoring and conventional learning methods. The population in this study were all works of students of class X IPA ( 3 classes) and students of class X IPS (3 classes) and the research sample was 36 students or 72 works. In this sample, two stages of action were given, namely initial sampling with the teaching and learning process using conventional learning methods. Based on the results of the study, the first test score average was 71.43 and the second test score was 82.74. The results of the mean difference test show that the average of the second value is better than the first value. Based on the results of hypothesis testing with a significance of $\alpha=0.5$ with $\mathrm{dk} 70$ obtained $\mathrm{t}$ table $=1.6669$. So the results of hypothesis testing obtained tcount 5.52> ttable 1.6669. So Ha is accepted as well as rejected by Ho, then the conclusion is that there are significant differences in the work of perspective drawing with the peer tutor learning method.
\end{abstract}

Keywords: Learning Methods ; Learning Outcomes.

\section{PENDAHULUAN}

Pendidikan merupakan suatu proses kegiatan mendidik yang dilakukan untuk membantu peserta didik menguasai seperangkat kemampuan seperti pengetahuan, keterampilan, nilai, dan sikap tertentu. Belajar merupakan suatu proses dari pendidikan untuk meningkatkan sumber daya manusia, proses belajar pada umumnya dilaksanakan di sekolah oleh dua pihak yaitu guru dan peserta didik. Hal ini berarti berhasil tidaknya pencapaian tujuan belajar bergantung pada bagaimana proses belajar mengajar yang dijalani oleh peserta didik, sebagai peserta didik yang menjadi tanggung jawab guru sebagai pendidik. Hubungan yang baik atau harmonis diharapkan adalah suasana yang 
menyenangkan agar peserta didik memiliki perasaan nyaman dan bersemangat untuk belajar sehingga termotivasi untuk mengembangkan potensi yang dimiliki dirinya secara maksimal. Kondisi yang harmonis dapat diharapkan meningkatkan hasil belajar peserta didik, salah satu upaya yang dapat dilakukan adalah dengan penerapan metode dalam proses belajar mengajar. Metode pembelajaran yang dimaksud memiliki tujuan untuk mencapai peningkatan dalam proses belajar mengajar. Beberapa metode pembelajaran yang dapat diterapkan pada proses belajar mengajar,termasuk metode tutor sebaya dan konvensional.

Proses pembelajaran menggambar perspektif di sekolah lebih cenderung dilakukan dengan cara ekspositori dan ceramah bertujuan untuk menjelaskan suatu topik atau objek agar peserta didik mendapatkan informasi atau wawasan yang luas, akan tetapi pembelajaran hanya berupa pemberian tugas kepada peserta didik sebelum memberikan penjelasan yang akurat. Belajar tidak hanya merujuk pada aktivitas organ berfikir otak. Belajar bertujuan untuk meningkatkan kualitas seseorang. Belajar adalah peningkat kompetensi. Belajar menjadi salah satu upaya seseorang untuk mewujudkan cita-citanya. Belajar berkenaan dengan tatanan dan nilai yang ditularkan dari generasi ke generasi. Belajar menjadi salah satu peradapan manusia. ( Prawiradilaga, $2012: 67$ ).

Seharusnya pembelajaran tidak hanya memberikan tema gambar yang akan dikerjakan, akan tetapi harus diajarkan tentang prinsip, kaidah dan teknik cara membuat sebuah gambar perspektif yang sesungguhnya. Lebih lanjut pembelajaran harus melihat bagaimana peserta didik saat mengerjakan tugas yang diberikan dengan tahap-tahap dalam proses menggambar perspektif. Dari tahap awal menentukan titik hilang, membuat dan menarik garis membentuk garis yang menghubung ke titik hilang sehingga menjadi gambar perspektif yang sebenarnya. Belajar adalah suatu proses usaha yang dilakukan seseorang untuk memperoleh sesuatu perubahan tingkah laku yang baru secara keseluruhan, sebagai hasil pengalamannya sendiri dalam interaksi dengan lingkungan. Perubahan tersebut akan nyata dalam seluruh aspek tingkah laku seseorang, baik perubahan pada dirinya $m$ aupun dalam kehidupan sehari-hari.( Slameto, 2010: 2 ).

Oleh karena itu belajar sangatlah penting untuk meningkatkan kualitas maupun kemampuan seseorang agar lebih luas dan bertambah. Belajar juga dapat dijadikan suatu aktivitas seseorang untuk mengasah otak atau pikiran sehingga dapat memperoleh ilmu pengetahuan yang luas dan lebih banyak lagi. Belajar harus menunjukan respons atau tanda-tanda adanya perubahan yang dapat membuktikan dari hasil dan perbuatan yang terukur.

Hasil belajar seni rupa adalah kemampuan yang dimiliki peserta didik setelah ia menerima pengalaman belajar mata pelajaran seni rupa. Sesuai silabus yang berlaku, pada materi gambar perspektif hasil belajar seni rupa peserta didik dititik beratkan hanya pada ranah psikomotorik (unjuk kerja). Dan hasil belajar juga merupakan kemampuan, sikap dan keterampilan yang diperoleh peserta didik setelah menerima perlakuan yang diberikan oleh guru sehingga dapat mengkonstruksikan pengetahuan itu dalam kehidupan sehari-hari. Hasil belajar suatu bukti nyata yang dicapai oleh peserta 
didik dalam menguasai kecakapan jasmani dan rohani di sekolah diwujudkan dalam bentuk nilai.

Menggambar perspektif adalah salah satu mata pelajaran praktek dalam seni budaya yang harus dicapai keberasilannya untuk memenuhi standart KKM nilai sekolah. Dengan pembelajaran menggambar perspektif peserta didik dilatih untuk mampu mengekspresikan penglihatan visualnya ke dalam kertas gambar dua dimensi. Dalam pembelajaran ini peserta didik diharapkan dapat mengapresiasi suatu karya seni yang dimulai dari karya mereka sendiri. Praktek menggambar perspektif peserta didik harus dibimbing dan menggunakan metode pembelajaran yang tepat, agar karya yang dihasilkan sesuai dengan capaian pembelajaran. Sesuatu proses pembelajaran dapat dikatakan baik, dikarenakan pada proses pembelajaran tersebut menggunakan metode yang tepat terhadap materi pelajaran yang akan diajarkan.

Kata perspektif berasal dari bahasa Italia, prospettiva yang berarti gambar pandangan. Konstruksi perspektif memungkinkan kita untuk menggambar sebuah benda atau ruang secara nyata diatas sebuah bidang datar (bidang gambar) atau untuk memperjelas sebuah rencana yang telah digambarkan secara proyeksi geometri (tampak atas, depan dan samping). (Suparyono, $2007: 2$ dalam jurnal Ilmu dan Seni, ISI Surakarta Vol. 5 no. 1, Juli). Dan perspektif atau sudut pandang merupakan teknik atau metode untuk menggambar objek-objek berupa benda, ruang (interior), dan lingkungan (eksterior) yang ukurannya lebih besar dari manusia. Dan kata prespektif berasal dari Bahasa Itali yaitu prospetiva yang memiliki arti gambar pandangan ( Yohanes Suprayono, 1982 : 7). Dalam gambar kerja yang berkaitan dengan sebuah perencanaan dan perancangan, presfektif biasanya digunakan untuk menjelaskan maksud rancangan secara tiga dimensi pada bidang datar dalam bentuk gambar prespektif. (Apriyatno, 2004:12).

Gambar perspektif adalah sebuah penampilan garis lurus, walaupun ketiga aturan visual ini adalah salah satu yang utama yang menjadi perhatian disini, tetapi ada juga faktor-faktor lain yang juga dapat diamati ketika melihat suatu objek atau pandangan. Sisi dan bayangan mengambil peranan penting dalam membantu kita untuk mendapatkan gambaran pemandangan atau objek secara lengkap. Adanya bayangan ketika permukaan disingkirkan dari cahaya, adanya bayangan ketika permukaan sedang berhadapan dengan cahaya, tetapi cahaya dihadang dari pencapaiannya dengan perantara benda atau objek. ( Gill, 2006:9).

Gambar perspektif berkaitan dengan pencapaian kesan ruang, kedalaman, dan dimensi ketiga, dalam batas-batas permukaan gambar datar. Ada beberapa prinsip visual yang berfungsi untuk tujuan ini, seperti pengecilan, perkiraan, konvergensi, naungan dan bayangan, dll. Dan dalam hukum menggambar prespektif tedapat ilmu perspektif yang merupakan seni dan ilmu menggambar suatu benda atau objek pada suatu bidang datar, gambar tersebut tampak seperti pandangan mata kita sehari-hari pada jarak tertentu. Dalam prinsip ilmu menggambar perspektif, apabila kedudukan benda yang dilihat dalam suatu pandangan mata semakin jauh maka objek akan semakin kecil dari ukuran benda sebenarnya. 
Pada perspektif, mulai dari satu titik hilang, dua titik hilang, dan tiga titik hilang bisa dibagi lagi dasarnya dalam gambar menjadi berbagai sudut pandang berdasarkan posisi mata kita dan tempat kita berada. Konstruksi perspektif memungkinkan kita untuk menggambarkan sebuah benda atau ruangan secara nyata diatas sebuah bidang datar (bidang gambar). Atau untuk memperjelas sebuah rencana yang telah digambarkan secara proyeksi geometri (pandangan atas, muka, samping).

Konstruksi perspektif adalah sebuah dasar pendidikan seni dan besar artinya untuk arsitek, seniman, orangorang tehnik dan sebagainya.( Suparyono, 1981 : 7 ). Gambar perspektif 2 titik hilang, biasanya dalam penggambaran digunakan dalam pengambilan suatu sudut pandang terhadap bangunan, ruangan dan juga sebuah interor bangunan.

Perspektif dua titik atau perspektif dengan dua buah titik lenyap digunakan ketika sudut-sudut objek menghadap ke pengamat gambar.

1. Tentukan garis batas cakrawala pada gambar. Gambarlah satu buah garis horizontal sebagai garis cakrawala, seperti pada cara pertama di atas.

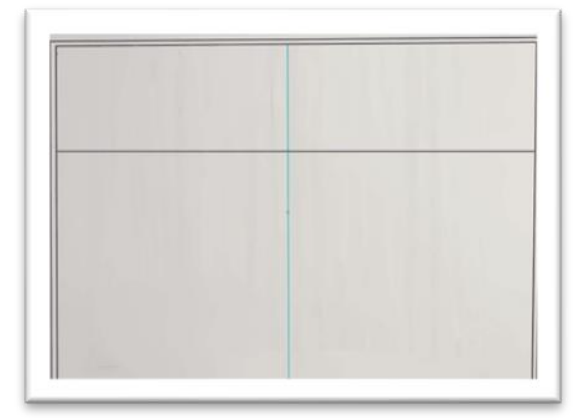

Gambar 1. Garis horizontal (Sumber : wikihow.com)
2. Tentukan sudut pandang yang merupakan perkiraan lokasi mata pengamat yang melihat gambar ini. Titik tersebut bisa berada di bawah kertas (di luar kertas gambar). Anda tidak perlu benar-benar menandai titik tersebut.

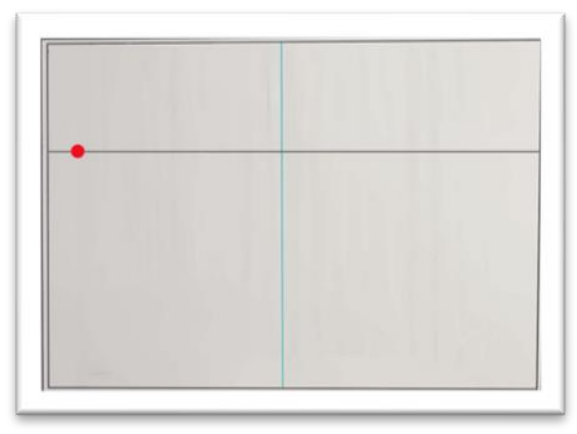

Gambar 2. Sudut pandang

(Sumber : wikihow.com)

3. Tentukan titik lenyap pertama. Cara umum untuk melakukannya adalah menggambar sebuah garis dengan sudut 60 derajat, dimulai dari sudut pandang pengamat ke arah kiri atas. Kemudian, tandai titik lenyap, yaitu di tempat garis tersebut berpotongan dengan garis cakrawala.

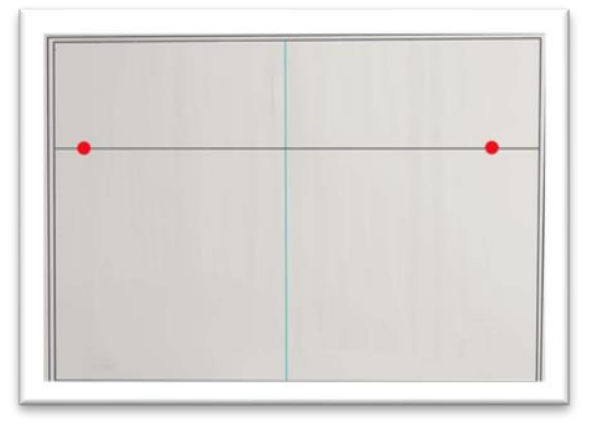

Gambar 3. Titik lenyap pertama (Sumber : wikihow.com)

4. Tentukan titik lenyap kedua. Untuk titik lenyap kedua, gambarlah sebuah garis dengan sudut 30 derajat, dimulai dari sudut pandang pengamat ke arah kanan atas. Sekali lagi, titik lenyap akan berada di perpotongan garis 
tersebut dengan garis cakrawala. Letak titik perpotongan dari sudut 60 dan 30 derajat bisa saja berbeda, tetapi besar sudut di antara garis yang dimulai dari titik mata pengamat sampai ke titik lenyap akan sama-sama membentuk sudut 90 derajat.

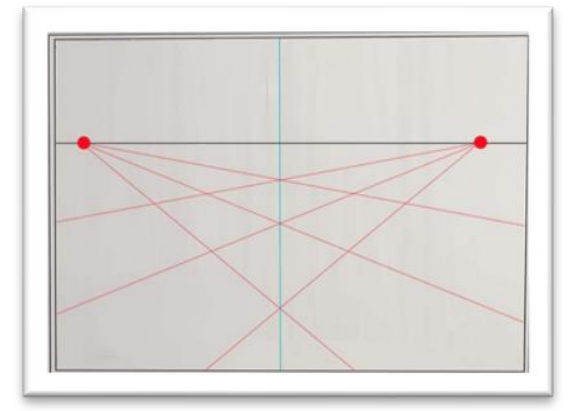

Gambar 4. Titik lenyap kedua (Sumber : wikihow.com)

5. Gambarlah objek dalam bentuk dasar kubus atau kotak dengan garis vertikal yang tegak lurus dan garis horizontal kiri dan kanan yang miring kearah titik lenyap. Gambar kubus merupakan bentuk dasar dalam menggambar perspektif berbentuk kubisme, semua gambar objek berbentuk kubisme didasari dari gambar kubus. Kemudian langkah berikutnya dapat membuat gambar perspektif dalam bentuk kubus sesuai yang diinginkan.

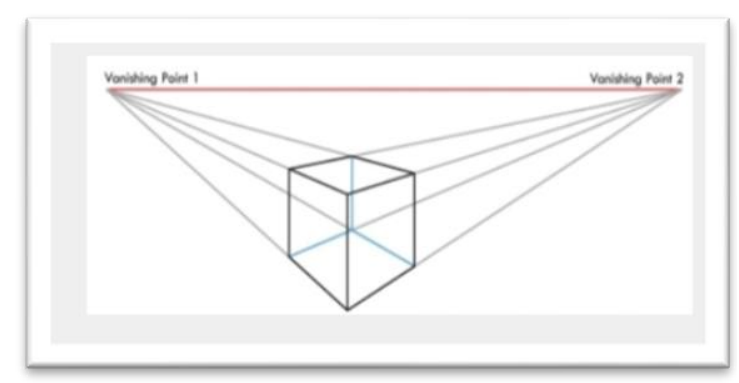

Gambar 2.8 Gambar kubus

(Sumber : Anidraw.net)

6. Gambarlah objek utama gambar dengan garis vertikal yang tegak lurus; garis horizontal kiri yang miring ke arah titik lenyap kiri; dan garis horizontal kanan yang miring ke arah titik lenyap kanan (semua garis horizontal harus berkumpul di titik lenyap kanan dan kiri jika garisnya digambar sejauh titik tersebut).

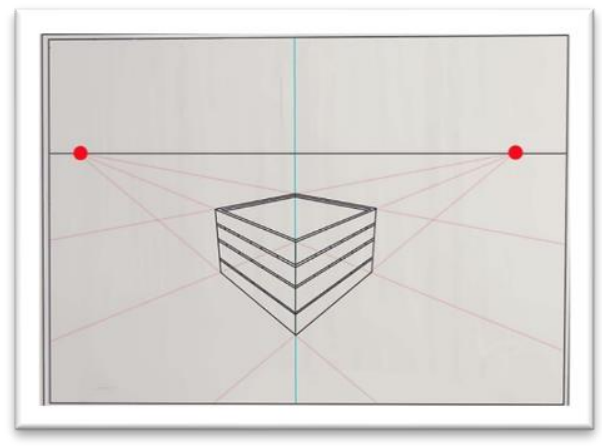

Gambar 6. Gambar objek (Sumber : wikihow.com)

7. Tambahkan detail pada gambar sesuai dengan garis-garis panduan horizontal yang digambar untuk objek utama gambar. Garis-garis ini akan menentukan proporsi ukuran objek saat berada lebih dekat atau lebih jauh dari sudut pandang pengamat gambar. Kemudian gambarlah objek yang ingin digambar sesuai keinginan dalam bentuk dasar kubus seperti kursi berikut ini :

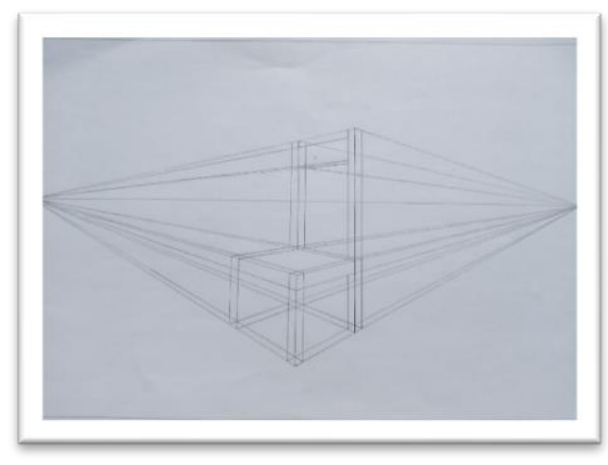

Gambar 7. Perspektif objek kursi (Sumber : Indra Mawan Sitepu)

Perbedaan pokok antara tatanan gambar perspektif satu titik (atas) dan 
tatanan gambar perspektif dua titik rendah dengan peserta didik yang hasil (kanan) adalah fakta bahwa dalam belajarnya lebih tinggi dalam suatu kelas. gambar perspektif dua titik, satu-satunya garis yang sejajar terhadap bidang gambar adalah garis vertikal.

Hukum-hukum

perspektif

diartikan sebagai norma-norma atau ketentuan-ketentuan tehnik yang pokok, yang harus dipedomani dalam menggambar perspektif. Menggambar perspektif adalah menggambar sesuai pandangan mata, sesuai dengan karakter pandangan mata yaitu sesuatu yang dekat akan kelihatan lebih besar dan lebih jelas, maka dalam menggambar berlaku demikian. Benda-benda yang semakin dekat dengan pengamatan akan diwujudkan dengan lebih besar dan jelas. Sebaliknya benda-benda yang semakin jauh dari pengamatan akan diwujudkan dengan bentuk semakin kecil dan samarsamar atau kabur. Demikian pula hal tersebut secara tehnik tetap menjadi acuan dalam melukis karya realis. Dengan ketentuan-ketentuan yang sudah mengikat untuk berkarya maka hal demikian disebutlah sebagai hukumhukum perspektif. (Sugito dan Wahyu,1996:7)

Tutor sebaya adalah seseorang atau beberapa orang peserta didik yang ditunjuk oleh guru sebagai pembantu guru dalam melakukan bimbingan terhadap kawan sekelas. (Arikunto 1986:77). Lebih lanjut dijelaskan tutor sebaya bahwa salah satu metode penilaian sikap yang perlu dilakukan dan dapat membantu guru melakukan penilaian secara lebih komprehensif adalah penilaian teman sejawat. (Ridwan Abdullah Sani 2014:216-217 ). Kelebihan metode tutor sebaya adalah dapat meminimalisir kesenjangan yang terjadi antara peserta didik yang hasil belajarnya

Dalam pembelajaran tutor sebaya terkait juga pada metode konvensional ditandai dengan ceramah yang diiringi dengan penjelasan, serta pembagian tugas dan latihan. Sejak dahulu guru dalam usaha menularkan pengetahuannya pada peserta didik, ialah secara lisan atau ceramah. Pembelajaran konvensional yang dimaksud adalah pembelajaran yang biasa dilakukan oleh para guru. Metode ceramah merupakan metode yang dapat dikatakan metode tradisional, karena sejak dulu metode ini telah dipergunakan sebagai alat komunikasi lisan antara guru dengan anak didik dalam proses belajar mengajar. ( Zain dan Djamarah, 2010: 97).

\section{HASIL DAN PEMBAHASAN}

Penelitian ini bertujuan untuk mengetahui pengaruh penerapan metode tutor sebaya terhadap hasil belajar menggambar perspektif siswa SMA Negeri 1 Sei Bingai tahun ajaran 2020/2021. Populasi dalam penelitian ini adalah gabungan dari kelas X SMA Negeri 1 Sei Bingai yang mendapatkan nilai yang rendah atau dibawah KKM. Pengambilan populasi dari 216 siswa terdiri dari 6 kelas terpilihlah populasi sebanyak 36 siswa. Namun setelah itu dilakukan pengambilan sampel dengan teknik total sampling maka populasi yang memenuhi kriteria untuk pengambilan sampel sejumlah 36 siswa. Setelah didapatkan sampel, maka dapat ditentukan ke 36 sampel tersebut merupakan kelas ekperimen. Dalam penelitian ini tahap pertama yang dilakukan adalah pengambilan sampel hasil karya siswa dengan metode konvensional, setelah itu peneliti melakukan penilaian terhadap hasil belajar menggambar perspektif tersebut kepada 3 
penilai sehingga peneliti mampu menentukan siapakah yang akan menjadi tutor didalam kelas eksperimen tersebut.
Tabel 1. Nama-nama Siswa Yang Menjadi Tutor

(Sumber : Indra Mawan Sitepu)

Setelah penentuan tutor maka langkah selanjutnya peneliti melakukan tes ke dua yaitu menggambar perspektif dengan objek kursi melalui metode pembelajaran tutor sebaya. Dalam metode tutor sebaya ini peneliti membagi kelas eksperimen tersebut menjadi 6 kelompok dan 1 kelompok terdiri dari 6 orang siswa dan sudah termasuk 1 orang siswa yang menjadi tutor disetiap kelompoknya.

\begin{tabular}{|c|l|c|}
\hline No & \multicolumn{1}{|c|}{ Nama Siswa } & Nilai $\bar{x}$ \\
\hline 1 & Alpina br sitepu & 91,33 \\
\hline 2 & Delon albetta ginting & 90,67 \\
\hline 3 & Elsa monika br ginting & 82,67 \\
\hline 4 & Raja arusta tarigan & 80,67 \\
\hline 5 & Riski imanuel sembiring & 85 \\
\hline 6 & Rizki sah putra & 81,67 \\
\hline
\end{tabular}

Tabel 2. Perbandingan Hasil Belajar Menggambar Perspektif

(Sumber : Indra Mawan Sitepu)

\begin{tabular}{|c|c|}
\hline Metode Pembelajaran Konvensional & Metode Pembelajaran Tutor Sebaya \\
\hline & \\
\hline Ade yola br ginting & Ade yola br ginting \\
\hline Kategori = B- & Kategori = B \\
\hline & \\
\hline & \\
\hline
\end{tabular}




\begin{tabular}{|c|c|}
\hline Metode Pembelajaran Konvensional & Metode Pembelajaran Tutor Sebaya \\
\hline & \\
\hline & \\
\hline Pebri irawan & \\
\hline Kategori $=$ B- & Pebri irawan \\
\hline
\end{tabular}

Berdasarkan gambar di atas, dilakukan dengan menggunakan uji bahwa hasil karya siswa menggambar Liliefors pada kelompok sampel, adapun perspektif menggunakan metode kriteria pengujian normalitas ini adalah pembelajaran tutor sebaya jauh lebih baik jika $\mathrm{L}_{\text {hitung }}<\mathrm{L}_{\text {tabel }}$ maka sampel dibandingkan kelompok hasil karya siswa berdistribusi normal. Jika $\mathrm{L}_{\text {hitung }}>\mathrm{L}_{\text {tabel }}$ menggambar perspektif dengan menggunakan metode konvensional. Hal ini dapat dilihat dari kelompok hasil karya menggambar perspektif siswa yang menggunakan metode pembelajaran tutor sebaya lebih baik dalam menerapkan beberapa hukum menggambar perspektif seperti kesejajaran, ketepatan arah, proporsi.

\section{Hasil Uji Normalitas}

Uji normalitas merupakan bagian uji persyaratan analisis untuk penelitian yang menggunakan data berbentuk kuantitatif dan dianalisis dengan cara statistik. Uji normalitas adalah untuk menguji apakah data yang digunakan memiliki sebaran data dengan distribusi normal. Uji kenormalan pada penelitian ini dapat dilakukan dengan cara nonparametik. Uji kenormalan nonparametik dikenal dengan nama uji liliefors (Sudjana, 1989:446 dalam Sugito).

Uji normalitas digunakan untuk mengetahui apakah data yang diperoleh terdistribusi normal atau tidak. Pengujian maka sampel tidak berdistribusi normal. Ringkasan perhitungan normalitas dapat dilihat pada tabel berikut.

Hasil perhitungan uji normalitas nilai hasil belajar siswa pada variabel metode tutor sebaya, taraf signifikan $\alpha=0,05$ dengan jumlah sampel $(\mathrm{N}=36)$ diperoleh $\mathrm{L}_{\text {hitung }}<\mathrm{L}_{\text {tabel }}$. Demikian nyata bahwa pengujian variabel tutor sebaya berasal dari populasi yang berdistribusi normal. 
Tabel 3. Ringkasan Hasil Analisis Uji Normalitas

(Sumber: Indra Mawan Sitepu)

\begin{tabular}{|c|c|c|c|c|c|}
\hline & & \multicolumn{3}{|c|}{} \\
\cline { 3 - 6 } No & Variabel & $\mathrm{N}$ & $\mathrm{L}_{\text {hitung }}$ & $\mathrm{L}_{\text {tabel }}$ & Ket \\
\hline 1. & $\begin{array}{c}\text { Metode } \\
\text { Tutor Sebaya }\end{array}$ & 36 & 0,0752 & 0,147 & Normal \\
\hline 2. & $\begin{array}{c}\text { Metode } \\
\text { Konvensiona } \\
\text { l }\end{array}$ & 36 & 0,0689 & 0,147 & Normal \\
\hline
\end{tabular}

\section{Hasil Uji Homogenitas}

Uji homogenitas digunakan untuk mengetahui apakah populasi berasal dalam homogenitas yang sama atau tidak. Uji homogenitas menggunakan teknik uji Bartlett, diperoleh $\mathrm{X}_{\text {hitung }}^{2}=0,6769$ dan $\mathrm{X}_{\text {tabel }}^{2}=3,841$ Sesuai dengan kriteria pengujian homogenitas data dengan teknik uji Bartlett, maka disimpulkan bahwa data hasil penelitian berasal dari sampel yang homogen dengan $\mathrm{X}_{\text {hitung }}^{2}<$ $\mathrm{X}_{\text {tabel }}^{2}$ yaitu $0,6769<3,841$.
3. Uji Kesamaan Dua Rata-Rata (Uji t)

Setelah melakukan uji persyaratan analisis data yaitu uji normalitas dan uji homogenitas telah diketahui bahwa kedua sampel berasal dari populasi yang normal dan homogen. Dari data perhitungan pada pada lampiran diperoleh bahwa $t_{\text {hitung }}=$ 5,52 . Harga $t_{\text {tabel }}$ dengan $\mathrm{dk}=(36+36)-2$ $=70$ dan signifikasi $\alpha=0,05$ adalah 1,6669. Adapun kriteria penerimaan dan penolakan yaitu:

Jika hasil $\mathrm{t}_{\text {hitung }}<\mathrm{t}_{\text {tabel }}$, maka $\mathrm{H}_{o}$ diterima dan tolak $\mathrm{H}_{a}$, jika hasil $\mathrm{t}_{\text {hitung }}>\mathrm{t}_{\text {tabel }}$, maka $\mathrm{H}_{a}$ diterima dan tolak $\mathrm{H}_{o}$. Sesuai dengan kriteria penerimaan dan penolakan hipotesis dapat disimpulkan bahwa ada perbedaan yang signifikan dari penerapan metode pembelajaran tutor sebaya terhadap hasil menggambar perspektif.

\section{KESIMPULAN}

Berdasarkan hasil penelitian yang telah dipaparkan dalam bab sebelumnya, maka dapat diuraikan simpulan yaitu Terdapat perbedaan nilai yang signifikan dari hasil karya menggambar perspektif kelas sample yaitu kelas X SMA Negeri 1 Sei Bingai 
dengan menggunakan metode konvensional dan metode tutor sebaya. Hal ini dapat dilihat dari nilai rata-rata yang diperoleh siswa metode konvensional sebesar 71,43 dan metode tutor sebaya sebesar 82,74. Dan Hasil karya menggambar perspektif kelas sample yaitu 36 siswa di kelas X SMA Negeri 1 Sei Bingai menggunakan metode tutor sebaya memiliki rata-rata : 82,74 dengan nilai terendah 63,33 dan nilai tertinggi 96,67 dengan frekuensi 1 . Sedangkan hasil karya menggambar perspektif kelas sample yaitu 36 siswa di kelas $\mathrm{X}$ SMA Negeri 1 Sei Bingai menggunakan metode konvensional memiliki rata-rata : 71,43 dengan nilai terendah 51,67 dan nilai tertinggi 91.33 dengan frekuensi 1. Jadi perolehan $\mathrm{t}_{\text {hitung }}$ $>t_{\text {tabel }}$ yaitu 5,52 $>1,6669$. Terlihat dari besarnya jarak antara $\mathrm{t}_{\text {hitung }}$ dengan $\mathrm{t}_{\text {tabel }}$ yaitu $5,52-1,6669=3,8531$.

\section{DAFTAR PUSTAKA}

Parawiradilaga. D .S. (2012). Wawasan Teknologi Pendidikan. Jakarta: Kencana Prenada Media Group.

Ridwan. A. S. (2014). Pembelajaran Saintifik. Jakarta:PT Bumi Aksara.

Slameto. (2010). Belajar dan factorfaktor yang mempengaruhinya. Jakarta: Rineka Cipta.

Sugiyono. (2016). Metode Penelitian Pendidikan: Pendekatan Kuantitatif, Kualitatif, $R \& D$. Bandung: Alfabeta. Suparyono, Y. (1981). Konstruksi Perspektif. Yogyakarta: Kanisius.

Sugito, dkk. (2017). Statistik Pendidikan Seni Rupa. Medan: UNIMED PRESS.

Sugito dan Wahyu. (1996). Hukumhukum perspektif konstruksi. Medan:

\section{UNIMED PRESS}

Purnomo, A. (2007). Prepektif Dalam Seni Lukis Trasisi Indonesia. Gelar Vol. 5 No. 1. Sugito dan Wahyu. (1996). Hukum-hukum perspektif konstruksi. Medan: UNIMED PRESS. 